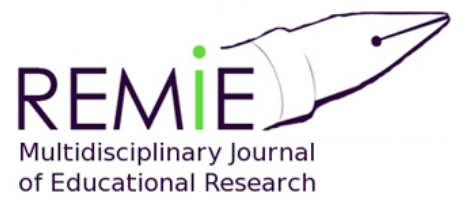

Instructions for authors, subscriptions and further details:

http://remie.hipatiapress.com

\title{
Learner Autonomy in Language Learning: Syrian Refugee EFL Learners' Perceptions and Readiness
}

Nilcan Bozkurt ${ }^{1}$, Fadime Yalcin Arslan ${ }^{1}$

1) Gaziantep University. Turkey

Date of publication: June $15^{\text {th }}, 2018$

Edition period: June 2018 - October 2018

To cite this article: Bozkurt, N., Yalcin Arslan, F. (2018). Learner Autonomy in Language Learning: Syrian Refugee EFL Learners' Perceptions and Readiness. Multidisciplinary Journal of Educational Research, 8(2), 115145. doi: $10.17583 /$ remie.2018.3028

To link this article: http://dx.doi.org/10.17583/remie.2018.3028

\section{PLEASE SCROLL DOWN FOR ARTICLE}

The terms and conditions of use are related to the Open Journal System and to Creative Commons Attribution License (CC-BY). 


\section{Learner Autonomy in Language Learning: Syrian Refugee EFL Learners' Perceptions and Readiness}

Nilcan Bozkurt

Gaziantep University
Fadime Yalcin Arslan

Gaziantep University

\section{Abstract}

This study examined Syrian refugee English as a Foreign Language (EFL) learners' perceptions regarding learner autonomy as well as their readiness for autonomy in English language learning. It also investigated the effects of grade and gender on learners' perceptions. A mixed-method research design was utilized, and findings indicated that neither grade nor gender had caused statistically significant differences in terms of Syrian refugees' perceptions of learner autonomy in language learning; nevertheless, both had caused statistically significant differences in terms of sub-scales. While the $8^{\text {th }}$ graders in this study perceived themselves as being more autonomous in terms of experience in language learning, the female students seemed more autonomous in terms of their perceptions of the role of teachers and feedback. Additionally, although the learners' perceptions regarding autonomy were slightly lower than their readiness for autonomy, there was a statistically significant relationship between their perceptions of learner autonomy and their readiness for autonomy in language learning. When their perceptions about learner autonomy increased, their readiness for autonomy also increased.

Keywords: autonomous learner, English as a foreign language, learner autonomy, refugee EFL learner 


\section{Autonomía del Aprendiz en El Aprendizaje de Un Idioma: Percepciones y Disposición de Refugiados Sirios en EFL}

Nilcan Bozkurt

Gaziantep University
Fadime Yalcin Arslan

Gaziantep University

\section{Resumen}

Este estudio examinó las percepciones de refugiados de Siria que estudian el inglés como Lengua Extranjera (EFL, por sus siglas en inglés) respecto de la autonomía del alumno, así como su disposición para ser autónomo en el aprendizaje del idioma inglés, y los efectos del grado y el género sobre las percepciones de los estudiantes. Se utilizó el método mixto, y los resultados indicaron que ni el grado ni el género causan diferencias estadísticamente significativas en términos de las percepciones de refugiados sirios sobre la autonomía del alumno al aprender idiomas; sin embargo, ambos causaron drásticas diferencias estadísticas en términos de sub escalas. Los estudiantes de $8^{\circ}$ grado se percibieron como más autónomos en términos de experiencia en el aprendizaje de idiomas, mientras las estudiantes parecían más autónomas en términos de la percepción que tenían sobre el papel de los maestros y la retroalimentación. Las percepciones de autonomía fueron ligeramente menores que la disposición para la autonomía, pero hubo una relación estadísticamente significativa entre percepciones de autonomía y su disposición de autonomía en el aprendizaje del idioma. El aumento de las percepciones de autonomía aumentó la disposición de los aprendices para autonomía.

Palabras clave: aprendiz autónomo, inglés como lengua extranjera, autonomía del alumno, aprendiz de EFL refugiado 
he movement of thoughts over previous years in education has shifted the center of teaching and learning from traditional methods, in which the teacher is the controller, to modern methods, in which learner is in the center of the education process. Especially in the late 1980s, learner-centeredness meant actively engaging learners in their learning processes (Nunan, 1989). Parallel to this principle, the idea of learner autonomy has maintained an important place in education. The concept of learner autonomy denotes enabling learners to take control of their learning not only in class but also in daily experiences (Benson, 2001; Little, 1996, 2007).

English teachers are essential to the development of learner autonomy, as they are responsible for creating a classroom culture that develops learners' abilities to behave autonomously (Barfield et. al., 2001); thus, teachers should be eager to play more challenging and different roles than in traditional learning, as they are the guiding figures (Benson, 2009). Language teachers, in particular, who have students from refugee backgrounds, play a significant role in supporting these students' potential for autonomy. This is because refugee students live in complex and difficult situations having left their homes by force and taken the risk of creating new lives elsewhere (Fong, 2004). Refugee learners bring "not only their local experiences into the classroom, but also their memories of experiences in their native country and their own visions of the future they desire in their new country" (Norton, 2000, p. 134). If the main aim of education is to prepare learners to address the demands of everyday life, firstly they should know how to interpret the world and express their emotions and ideas about it. As expressing oneself is made possible through language, language teachers (especially English language teachers whose missions are to teach the international language) play crucial roles in preparing students for autonomous language learning. In this way, teachers are expected to create a classroom learning atmosphere that supports learner autonomy by taking into consideration learners' needs and expectations. This initially may involve the investigation by teachers of their learners' perceptions and secondarily an assessment of students' readiness in order to increase their awareness regarding the benefits of autonomous learning. Behaviors are controlled by experiences and beliefs, and learners' beliefs can contribute to 
or hinder their potential for autonomy (Cotterall, 1995a.). To illustrate, Horwitz (1987) claims that one's having wrong beliefs about learning a language may result in his/her applying less efficient learning methods. This means that it is beneficial for teachers to recognize the beliefs and perceptions of learners in order to assess these learners' readiness for autonomy and adjust their teaching and learning processes accordingly (Cotterall, 1995b.).

The present study's participants and subject deem it as significant, as studies investigate refugees in terms of autonomy in English language learning. Thus, this study contributes both to the field of refugee studies and to the language-teaching field. It investigates Syrian refugee learners' perceptions regarding autonomy in English language learning as well as their readiness for autonomy. It also explores the relationship between these learners' perceptions about autonomy in language learning and their readiness for it. It is assumed in this study that an autonomous environment in classes can be possible by increasing the awareness of teachers and learners regarding the potential for autonomy among learners. This research responds to the research questions below:

(1) Does grade $\left(6^{\text {th }}, 7^{\text {th }}\right.$ and $\left.8^{\text {th }}\right)$ cause a significant difference in terms of Syrian refugee learners' perceptions of learner autonomy in English language learning?

(2)Does gender play a significant role in shaping Syrian refugee learners' perceptions of learner autonomy in English language learning?

(3) Does a statistically significant relationship exist between Syrian refugee learners' perceptions of learner autonomy and their readiness for autonomy in English language learning? 


\section{Literature Review}

\section{Learner Autonomy and Readiness for Autonomous Language Learning}

The meaning of the term "learner autonomy" has differed among education researchers; however, several definitions present clear ideas about this term (Zou, 2011). According to Holec (1981, p.3), regarded as the father of the field of language learning, "learner autonomy is the ability to take charge of one's learning". Autonomy - "feeling free and volitional in one's actions" (Deci, 1995, p.2) - is an essential need for human beings. It also denotes ability and is as relevant to learning as to any other aspect of life. "This ability is not inborn but must be acquired either by 'natural' means or (as most often happens) by formal learning, i.e. in a systematic, deliberate way" (Holec, 1981, p.3). Teaching and learning a language is occurs by means of an extensive process in which language is autonomously learned and taught (Quinn, 1974). Language learning is a never-ending process that wants learners to acquire how to develop autonomy and responsibility for their learning in all fields of their lives. Therefore, autonomy should be considered from different angles.

Many scholars have examined the relationship between autonomy and learners' readiness (Cotterall, 1995; Karabıy1k, 2008; Koçak, 2003; Littlewood, 2000). The significant factors affecting readiness for autonomy are as follows: learners' possession of decision- making abilities; learners' beliefs about their own roles and their teachers' roles; motivation; and the use of metacognitive learning strategies. Learners' possession of decisionmaking abilities enables them to participate in autonomous language learning. Holec (1981) claims that learners can make decisions in their learning by setting goals, choosing the content of their learning, and deciding which techniques to utilize. Nunan (1997) and Dickinson (1991) focus on the application of these decisions not only in the class but also beyond the classroom.

Learners' opinions about their roles and duties as well as their teachers' roles and responsibilities greatly affect the improvement of autonomy (Lamb, 2008). To illustrate, Cotterall's study (1995a.) concluded that 
learners who regarded teachers as facilitators had been more willing to learn autonomously than those who regarded teachers as authoritative figures. Although it is difficult for teachers to change their roles as suppliers of knowledge and controllers of the learning process into managers and facilitators of the learning process, Thanasoulas (2000), Zhou and Chen (2005) note that there are three steps which ensure this transfer: a) encouraging learners to identify their weaknesses, strengths, and needs in an independent way; b) promoting autonomous learning both in and out of the classroom so that learners may decide and work independently; and c) providing learners choices through the allotment of various tasks during learning.

Motivation is essential for affecting the manifestation of learner autonomy. Chan, Spratt and Humphreys (2002) support this idea by claiming that higher levels of motivation enable learners to participate more in autonomous learning activities outside the classroom. According to Dickinson (1995), learners' awareness of their responsibility for their learning depends on high motivation levels. Lee (1998) regards this interdependence as learners' voluntariness, a pre-requirement for learning language independently. Similarly, Littlewood (1996) uses interchangeably the terms "willingness," which is a significant component of autonomy in foreign language learning, and "motivation."

The improvement of learner autonomy is influenced by the usage of metacognitive learning strategies, also mentioned as regulatory skills or self-management strategies in research. By employing metacognitive strategies, learners can develop attitudes towards autonomous learning and regulate their own learning (Victori \& Lockhart, 1995). According to Zhou and Chen (2005, p.49), attitude means "meta-cognitive knowledge," which shapes new beliefs and values among learners; thus, learners may be inclined to seek new learning opportunities beyond the classroom in order to enhance their autonomy (Oxford, 1990).

One of the most significant aims of language education is to advance learner autonomy in English language classes. Researchers have conducted many studies on learner autonomy in language teaching (Benson, 2001; Deci, 1995; Dickinson, 1987; Kelly, 1996; Little, 1994, 2007). Still, there is a need to conduct more studies on refugee learners, who struggle to 
continue their education in countries in which languages and cultures are different from their own. No matter where learners are, they always have the potential to learn English. Moreover, creating an autonomous learning environment is possible anywhere as long as teachers and learners are aware of learners' potential for autonomous learning. Aside from enhancing their language learning, autonomy also enables learners to understand the world from different perspectives and change themselves, when necessary (Kenny, 1993). In conclusion, additional research is needed on the relationship between language learning and autonomy (Benson, 2001).

\section{Methodology}

\section{Participants}

Two hundred and fourteen Syrian students in the $6^{\text {th }}, 7^{\text {th }}$ and $8^{\text {th }}$ grades from Syrian refugee schools in Adana, Turkey, participated in the study. The schools functioned as four different temporary education centers (TEC) located in areas that had been quickly populated by immigrants living in low socio-economic conditions. Nine of the participants were from TEC1, 63 of them were from TEC2, 32 of them were from TEC3, and 110 of them were from TEC4. 46 of them were $6^{\text {th }}$ graders, 64 of them were $7^{\text {th }}$ graders, and 103 of them were $8^{\text {th }}$ graders. 136 students were female and 61 of them were male. The student participants' ages varied from 12 to 14 years, and their English levels were similar. They came from different cities in Syria; therefore, they differed in terms of background, socio-economic status, Arabic language proficiency, and standard of living. Eight Syrian English teachers from the TECs participated in the semi-structured interview component of this study. The teacher participants were also Syrian. There were two females and six males. The teachers had English-teaching certificates, $(\mathrm{N}=2)$, Bachelor's degrees $(\mathrm{N}=5)$, and Master's degree $(\mathrm{N}=1)$. They had 0-4 years of experience $(\mathrm{N}=2), 5-9$ years of experience $(\mathrm{N}=3), 10$ 14 years of experience $(\mathrm{N}=1), 15-19$ years of experience $(\mathrm{N}=1)$, and more than 20 years of experience $(\mathrm{N}=1)$ as English language teachers. They volunteered to contribute to the study by expressing their opinions about the results gathered by the quantitative data. 


\section{Data Collection Instruments}

The data were collected via both quantitative and qualitative instruments, and a mixed- method design was employed to investigate Syrian refugee EFL learners' perceptions about autonomy and their readiness for autonomy in language learning (Bozkurt \& Yalcin Arslan, 2017). Three questionnaires were administered: a) a questionnaire regarding participant demographics, b) Cotterall's (1995b.) Questionnaire about Language Learning Beliefs and Autonomy, and c) Nasöz's (2015) Learner Autonomy Readiness Questionnaire.

The first questionnaire dealt with the demographic information of the participants such as gender and grade, while the second and third questionnaire utilized a 5-point Likert scale ("strongly agree," "agree," "neither agree nor disagree," "disagree," "strongly disagree") in order to obtain learners' perceptions regarding autonomy in language learning and their readiness. Some questionnaire items were omitted because Cotterall (1995a.) states, "Only factor loadings of 0.43 and greater should be considered statistically significant (see Stevens, 1986, p. 344)." Consequently, variables having factor loadings of less than 0.43 were not included.

The scale of the second questionnaire, developed by (Cotterall, 1995a.), consisted of 17 items and 6 factors as follows: Role of Teacher, Role of Feedback, Learner Independence, Learner Confidence, Experience of Language Learning, and Approach to Studying. The second questionnaire investigating EFL learners' perceptions about autonomous language learning was analyzed according to four components of autonomy: motivation, students' views on their own roles and teachers' roles, decisionmaking abilities, and meta-cognitive strategy use. The scale of the third questionnaire, developed by Nasöz (2015), consisted of 31 items and investigated EFL learners' readiness for autonomous language learning.

Total scale reliabilities of the "Language Learning Beliefs and Autonomy" and "Learner Autonomy Readiness" questionnaires were measured using Cronbach alpha values. An $\propto$ of .83 and .89 were obtained for the two scales, respectively, satisfying the .70 criterion of Nunnally (1978). Before 
conducting the questionnaires of the study, they were translated from English to Arabic to enable the participants to understand the items more clearly as their native language was Arabic. After the initial translation was completed, the equivalence of the questionnaires' two versions was ensured by reverse translation which was made by two experts.

To support the results of the statistical data, eight Syrian English teachers and 33 students were interviewed and asked about the results of the research concerning the learners' perceptions about autonomy and their readiness for autonomy in language learning (Bozkurt \& Yalcin Arslan, 2017).

\section{Data Analysis}

Demographic questions were analyzed by utilizing descriptive statistics. One-way ANOVA and t-test were used to investigate if grade $\left(6^{\text {th }}, 7^{\text {th }}\right.$ and $\left.8^{\text {th }}\right)$ or gender had caused any significant differences in terms of Syrian refugee learners' perceptions of learner autonomy in language learning. A Pearson product-moment correlation was employed to investigate the significance of the relationship among perceptions of autonomy and readiness for autonomy.

Content analysis was used to examine the qualitative data, which was based on the ideas of the teachers and the students regarding the findings gathered from the semi-structured interviews. The transcribed raw data was then systematized to follow inductive content analysis steps. Thus, the content was initially coded and then themes were shaped around the emerging codes. In order to ensure the trustworthiness of this study, periodical help of a competent expert was taken for peer debriefing throughout the process of data analysis. To enable transferability thick description of the phenomenon was enriched by using quotes from the participants' responses in the result section. Lastly in order to provide interrater reliability, there was one more scorer except for the researcher (Fraenkel, Wallen \& Hyun, 2006). This section of data was also used to support the results of the statistical analyses. 


\section{Results and Discussion}

The findings and discussion of the research are presented under the following titles of each research question:

\section{The Role of Grade on Syrian Refugee EFL Learners' Perceptions of Learner Autonomy in Language Learning}

The first research question of the study sought to identify whether there were differences among grade levels $\left(6^{\text {th }}, 7^{\text {th }}\right.$ and $\left.8^{\text {th }}\right)$ in terms of Syrian refugee EFL learners' perceptions of learner autonomy in language learning. Table 1 below presents the mean scores of the participants' perceptions of autonomy in terms of grade (Bozkurt \& Yalcin Arslan, 2017).

Table 1

Means, Standards Deviations, and Sample Sizes for Grade on the Factors of the Questionnaire about Language-Learning Beliefs and Autonomy.

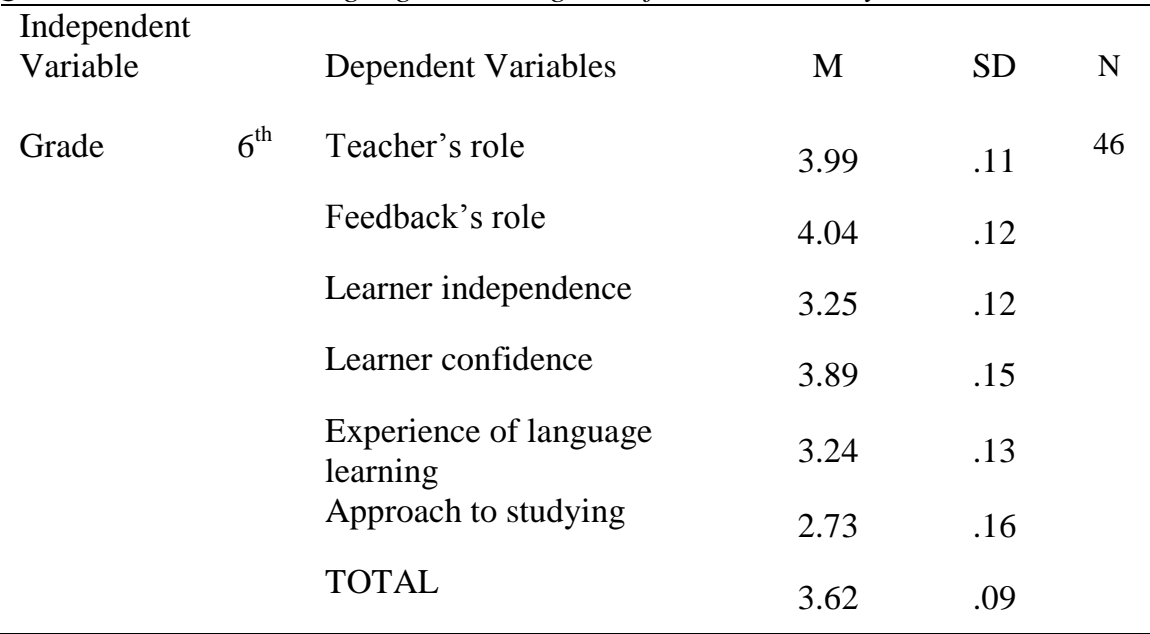


Table 1. Cont.

Means, Standards Deviations, and Sample Sizes for Grade on the Factors of the Questionnaire about Language-Learning Beliefs and Autonomy.

\begin{tabular}{|c|c|c|c|c|c|}
\hline \multicolumn{2}{|l|}{$\begin{array}{l}\text { Independent } \\
\text { Variable }\end{array}$} & Dependent Variables & M & SD & $\mathrm{N}$ \\
\hline \multirow{14}{*}{ Grade } & $7^{\text {th }}$ & Teacher's role & 3.85 & .12 & 63 \\
\hline & & Feedback's role & 3.87 & .11 & \\
\hline & & Learner independence & 3.26 & .11 & \\
\hline & & Learner confidence & 3.72 & .11 & \\
\hline & & $\begin{array}{l}\text { Experience of language } \\
\text { learning }\end{array}$ & 3.09 & .12 & \\
\hline & & Approach to studying & 3.02 & .14 & \\
\hline & & TOTAL & 3.55 & .08 & \\
\hline & $8^{\text {th }}$ & Teacher's role & 3.82 & .09 & 101 \\
\hline & & Feedback's role & 3.85 & .08 & \\
\hline & & Learner independence & 3.38 & .08 & \\
\hline & & Learner confidence & 3.84 & .10 & \\
\hline & & $\begin{array}{l}\text { Experience of language } \\
\text { learning }\end{array}$ & 3.58 & .09 & \\
\hline & & Approach to studying & 2.94 & .10 & \\
\hline & & TOTAL & 3.62 & .06 & \\
\hline
\end{tabular}

To have a more precise understanding of the difference and to obtain information about the role of grade on learners' perceptions, inferential analysis was employed alongside a One-Way ANOVA. Table 2 below summarizes the ANOVA findings for the effect of grade on each of the subscales. 
Table 2

Grade's Effect on Learners' Perceptions of Learner Autonomy

\begin{tabular}{llccc}
\hline $\begin{array}{l}\text { Independent } \\
\text { Variable }\end{array}$ & $\begin{array}{l}\text { Dependent } \\
\text { Variables }\end{array}$ & $\mathrm{F}$ & $\mathrm{P}$ & $\eta^{2}$ \\
\hline Grade & Teacher's role & .71 & .49 & .007 \\
& $\begin{array}{l}\text { Feedback's role } \\
\text { Learner }\end{array}$ & 1.02 & .36 & .010 \\
& $\begin{array}{l}\text { independence } \\
\text { Learner } \\
\text { confidence } \\
\begin{array}{l}\text { Experience of } \\
\text { language learning } \\
\text { Approach to }\end{array}\end{array}$ & .41 & .64 & .004 \\
studying & .98 & $.00 *$ & .004 \\
TOTAL & .32 & .72 & .053 \\
\hline
\end{tabular}

Note. *Difference is significant at $p<.05$

As seen in the table above, the results suggested that while grade did not affect refugee students' total perceptions in terms of autonomy, there was a significant difference among grades only in terms of refugee students' perceptions of experience of language learning. When Scheffe Post-Hoc analysis results were examined, the $8^{\text {th }}$ graders were observed to have perceived themselves as more experienced in language learning than the $6^{\text {th }}$ and $7^{\text {th }}$ graders $\left(8^{\text {th }}>6^{\text {th }}>7^{\text {th }}\right)$; nevertheless, no significant differences were observed among other levels or on other sub-scales.

Most of the interviewed students stated that there was a relationship between grade and autonomy in terms of experience in language learning. They indicated that as the $8^{\text {th }}$ grade students were older and more responsible, they had more experiences and information about the language and could better realize the importance of English. As individuals continue growing and developing simultaneously throughout life (Erikson, 1963; Ryff, 1995; Sheldon \& Kasser, 2001), the fact that older learners are seen as more equipped in terms of knowledge or experiences could be understood 
from the opinions of the students. According to Chadler and Connell (1987), older children have significantly more internalized analyses towards their tasks when compared with younger children. Furthermore, Sheldon, Kasser, Houser-Marko, Jones and Turban (2005) emphasized that chronological age can be essential to experiential autonomy.

Although the teachers also accepted the relation between grade and experience in language learning, they did not agree on the role of grade on the perceptions of the students and claimed that the students had similar perceptions towards learner autonomy in language learning. The reasons for the similarities in the perceptions of the students according to the teachers were learners' different life stages which could be observed from different perspectives such as cognitive, physical, and psychosocial development (Bastable \& Dart, 2008). Firstly most of the teachers claimed that the cognitive and psychological development of the students were similar due to their being members of a similar age group; therefore, it was normal for them to have similar perceptions of learner autonomy in language learning. According to Piaget's theory, there are stages in terms of cognitive development. The student participants of this study were at the beginning of the formal operations stage, a stage at which they are able to think critically or determine solutions to the problems they face (Huitt \& Hummel, 2003). Secondly, some of the teachers stated that regarding past experiences, present feelings, and circumstances, the learners' levels of well-being after the Syrian Crisis were so similar that they also had similar perceptions of learner autonomy in language learning. As chronological age is not the only indicator of the ability of an individual (Santrock, 2006; Vander Zandel, Crandell \& Crandell, 2007), the psychological development of the learners also results in their having similar perceptions of learner autonomy. Normative history-graded influences like wars or normative life events can be a turning point in an individual life (Santrock, 2006; Vander Zandel et. al, 2007). That is, there can be sharp differences in personal autonomy, especially during teenage years (Dornsbush, Erickson, Laird \& Wong, 2001; Bartle, Anderson \& Sabatelli, 1988).

Thirdly, one of the teachers interpreted differently the relation between grade and perception of learner autonomy in language learning by stating 
that "the relation can be between the learners' perceptions towards learner autonomy and the time of study no matter the grade". Learners' perceptions can be directed when they are aware of learning strategies because children have the capacity of eventually being autonomous when that capacity is nurtured by adults with whom they interact (Feinberg, 1980). Moreover, although all the student participants regarded learner autonomy in language learning similarly due to their similar past experiences, present feelings, and circumstances as a consequence of war, autonomy can be developed by means of relationships with both family and people outside the family (Purdie, Carrol \& Roche, 2004).

\section{The Role of Gender in Shaping Syrian Refugee EFL Learners' Perceptions of Learner Autonomy in Language Learning}

The role of gender in determining Syrian refugee EFL learners' perceptions of learner autonomy in language learning was investigated as the second research question of the study. Table 3 below presents the average scores of the participants' perceptions of autonomy in terms of gender.

Table 3

Means, Standards Deviations, and Sample Sizes for Gender on the Factors of the Questionnaire about Language Learning Beliefs and Autonomy

\begin{tabular}{|c|c|c|c|c|c|}
\hline $\begin{array}{l}\text { Independent } \\
\text { Variable }\end{array}$ & & Dependent Variables & M & SD & $\mathrm{N}$ \\
\hline \multirow[t]{7}{*}{ Gender } & \multirow[t]{7}{*}{ Female } & Teacher's role & 3.92 & .07 & \multirow[t]{7}{*}{136} \\
\hline & & Feedback's role & 3.94 & .06 & \\
\hline & & Learner independence & 3.40 & .07 & \\
\hline & & Learner confidence & 3.86 & .08 & \\
\hline & & $\begin{array}{l}\text { Experience of language } \\
\text { learning }\end{array}$ & 3.40 & .08 & \\
\hline & & Approach to studying & 2.93 & .09 & \\
\hline & & TOTAL & 3.64 & .05 & \\
\hline
\end{tabular}


Table 3 (Cont.)

Means, Standards Deviations, and Sample Sizes for Gender on the Factors of the Questionnaire about Language Learning Beliefs and Autonomy

\begin{tabular}{|c|c|c|c|c|}
\hline $\begin{array}{l}\text { Independent } \\
\text { Variable }\end{array}$ & Dependent Variables & M & SD & $\mathrm{N}$ \\
\hline \multirow{8}{*}{ Gender } & & & & \\
\hline & Teacher's role & 3.62 & .13 & 60 \\
\hline & Feedback's role & 3.69 & .14 & \\
\hline & $\begin{array}{l}\text { Learner } \\
\text { independence }\end{array}$ & 3.18 & .12 & \\
\hline & Learner confidence & 3.72 & .15 & \\
\hline & $\begin{array}{l}\text { Experience of } \\
\text { language learning }\end{array}$ & 3.28 & .12 & \\
\hline & $\begin{array}{l}\text { Approach to } \\
\text { studying }\end{array}$ & 2.87 & .13 & \\
\hline & TOTAL & 3.44 & .10 & \\
\hline
\end{tabular}

A t-test was used to obtain information regarding the role of gender on Syrian refugee EFL learners' perceptions of learner autonomy in language learning. Table 4 below summarizes the t-test findings for the effect of gender on each of the sub-scales.

Table 4

Gender's Effect on Learners' Perceptions of Learner Autonomy

\begin{tabular}{llcl}
\hline $\begin{array}{l}\text { Independent } \\
\text { Variable }\end{array}$ & Dependent Variables & $\mathrm{T}$ & $\mathrm{P}$ \\
\hline Gender & Teacher's role & 4.26 & $.04^{*}$ \\
& Feedback's role & 3.74 & $.05^{*}$ \\
& Learner independence & 1.71 & .11 \\
& Learner confidence & .77 & .37 \\
& Experience of language & .68 & .39 \\
& learning & & .03 \\
& Approach to studying & .03 & .08 \\
\hline
\end{tabular}

Note.* Difference is significant at $p<.05$ 
As Table 4 displays, the t-test results yielded a non-significant result pertaining to students' total perceptions; however, they revealed a significant effect of gender on both the teacher's role and feedback's role, but not on other sub-scales such as learner independence, learner confidence, experience of language learning, and approach to studying.

When the mean scores of males and females were calculated, the results indicated that female EFL learners' perceptions of learner autonomy were higher than those of their male counterparts in terms of the teacher's and feedback's role in language learning. That is, the male students depend more on the teacher's guidance and feedback compared to the females.

When the interviewed students expressed their opinions about the relationship between gender and autonomy, they generally said that their female friends were more eager to have responsibilities in learning English as they cooperated with their teachers more than their male friends $(n=19)$. Some of the students added that females were eager to learn English, yet males also could take responsibility for their learning when they possessed the required motivation. When interrogated regarding the possible reasons for male students' perceptions, teachers agreed on three reasons: a) compared with females, social pressure on males to address life challenges caused them to have less opportunity for autonomy in lessons $(n=6), b)$ females were more responsible and knowledgeable of language-learning strategies $(n=6), c)$ females could have more free time and opportunity to become autonomous $(n=4)$.

Although males develop autonomous behaviors more rapidly than females (Douvan \& Adelson, 1966; Coleman, 1961), cross-cultural differences can inversely affect their development of autonomy (Tung \& Dhillon, 2006). For instance, socialization is not the same for males and females. Whereas males are supported to be more autonomous, females are praised for their passivity. Then, males become more active in daily life and sometimes find themselves taking over family roles which are not appropriate for their ages. At the same time, females achieve psychosocial maturity and try to reduce their total dependency (Greenberger, 1984; Greenberger \& Sorenson, 1974). Then, females begin to resist their culturally structured identifications (Rind, 2015) and learning 
environments. Although, due to social norms, their actions are limited, they can have a chance to express themselves in the social environment of school. There, they can recognize that "education is a key indicator of women's status" (Al Riyami, Afifi \& Mabry, 2004) and succeed in performing better by cooperating with their teachers. For instance, a number of researchers (i.e. Ehrman \& Oxford, 1990; Oxford, 1993; Ellis, 1994) agree on the superiority of females in language development.

A good language learner is supposed to find strategies for coping with difficulties in the target language learning process (Rubin, 1975). According to Teacher Five, "female students use learning strategies much more than male students do," and many studies also highlight that females are better than males in terms of using language-learning strategies (Watanable, 1990; Green \& Oxford, 1995; Sy, 1994; Bacon \& Finnemann, 1992). As learning strategies enable learners to monitor their conscious methods of learning (Chamot, Barnhardt, El-Dinary \& Robbins, 1999), it can be concluded that females who use those strategies more frequently than males can take more responsibility for their learning and regulate the learning process successfully.

While applying learning strategies to control their learning progress, learners express their feelings about themselves, and their performance is influenced by internal perceptions (Fazey \& Fazey, 2001). They take more responsibility for their learning when they trust themselves and believe that they are "the control of the outcome" (Dickinson, 1995). In gender-based studies, females are likely to have more positive perceptions, higher motivation, and more awareness of learning strategies (Oxford, Nyikos \& Ehrman, 1988), so they take more responsibility and exert more effort in language learning (Salem, 2006). In this study, the quantitative results also demonstrated that the female students perceived themselves as being more autonomous in terms of the teacher's role and feedback's role; hence, they depended less on their teachers but still cooperated with them and took more responsibility for their learning. This means that having more positive attitudes or perceptions about themselves in language learning makes learners perform more autonomous. 


\section{The Relationship between Perceptions of Learning Autonomy and Readiness for Autonomy among Syrian Refugee EFL Learners}

The study also intended to identify whether there was a statistically significant relationship between the refugee EFL learners' perceptions of learner autonomy and their readiness for autonomy in language learning, and Table 5 presents the mean scores of the participants' perceptions of learner autonomy and their readiness for autonomy in language education.

Table 5

Means and Standards Deviations for Syrian Refugee EFL Learners' Perceptions of Learner Autonomy and Their Readiness for Autonomy in Language Learning

\begin{tabular}{lll}
\hline Variables & $\mathrm{M}$ & $\mathrm{SD}$ \\
\hline & & .58 \\
Readiness of autonomy & 3.68 & .63 \\
Perceptions for autonomy & 3.59 & \\
\hline
\end{tabular}

Note. $\mathrm{M}=$ mean $\mathrm{SD}=$ standard deviation

As Table 5 displays, descriptive results pointed out that students scored higher on Nasöz's Learner Autonomy Readiness Questionnaire (2015) than on Cotterall's Questionnaire about Language Learning Beliefs and Autonomy (1995). This indicated that Syrian refugee students' readiness for autonomy in English language learning was moderately high; and appeared to be higher than their perceptions of autonomous English learning scores.

A Pearson product-moment correlation was utilized to look at the relationship between Syrian refugee EFL learners' perceptions of learning autonomy and readiness for autonomy in language learning. Table 6 shows the size of the coefficient of correlation between perception of learning autonomy and readiness for autonomy for autonomy in Syrian refugee EFL learners. 
REMIE-Multidisciplinary Journal of Educational Research, 8(2) 133

Table 6

Relationship between Perception of Learning Autonomy and Readiness for Autonomy

\begin{tabular}{|c|c|c|c|}
\hline & & Readiness for autonomy & $\begin{array}{l}\text { Perception of learning } \\
\text { autonomy }\end{array}$ \\
\hline \multirow{2}{*}{$\begin{array}{l}\text { Readiness } \\
\text { for autonomy }\end{array}$} & Pearson & 1 & $.702^{*}$ \\
\hline & Sig. (2-tailed) & & .000 \\
\hline \multirow{3}{*}{$\begin{array}{l}\text { Perception of } \\
\text { learning } \\
\text { autonomy }\end{array}$} & Pearson & $.702^{*}$ & 1 \\
\hline & Correlation & & \\
\hline & Sig. (2-tailed) & .000 & \\
\hline
\end{tabular}

Note. *Correlation is significant at the 0.01 level (2-tailed) $\quad \mathrm{N}=214$

According to Table 6 , the results revealed a significant correlation coefficient with $\mathrm{r}=.70, \mathrm{p}=.00(\mathrm{p}<.05)$. That is, Syrian refugee students' perceptions of and readiness for English language learning were strongly related to one another; suggesting that when students' perceptions of autonomy increased, their readiness for autonomy also increased. This implies that when students' perceptions of autonomy increase, their readiness for autonomy also increases (Bozkurt \& Yalcin Arslan, 2017).

The findings above are similar to those of Cotterall's (1995), Gan's (2004), Yildirim's (2008), and Orawiwatnakul and Wichadee's (2017) studies, which also demonstrated a positive relationship to exist between language-learning behaviors and beliefs about language- learning autonomy. Learners who have high perceptions of autonomy behave more autonomously in learning (Orawiwatnakul \& Wichadee, 2017). When they have a higher sense of autonomy, they can also monitor their own learning more frequently (D’Ailly, 2003). In other words, positive perceptions of autonomy can provoke autonomous behaviors. Ushioda (2011), Chan, Spratt and Humphreys (2002) exemplified the relationship between perceptions of autonomy and readiness for autonomy by stating that learners could engage in autonomous behaviors when motivated. This means when they have positive perceptions about learning, they become better prepared to behave autonomously. From a different point of view, Dörnyei and Csizér (1998) described the correlation. In their study, they 


\section{Bozkurt \& Yalcin Arslan - Refugee EFL Learners' Autonomy}

stated that autonomy caused motivation. When motivation is regarded positively, it can be said that higher levels of readiness for autonomous behaviors also result in higher perceptions of autonomy. That is, as it is also claimed in this study, readiness for autonomy and perceptions of autonomy significantly impact each other.

The teacher participants agreed that their students' perceptions were slightly lower than their readiness for autonomy and provided the following reasons for this difference: a) physically and psychologically bad circumstances $(n=4), b)$ a lack of materials in the learning process $(n=3)$, c) a lack of knowledge and ability in the target language $(n=3)$, and d) their not being native speaker $(n=2)$. The teachers highlighted both the physically and psychologically bad circumstances which their students faced after the war, and they stated that the students had been affected by those circumstances so much that their perceptions of themselves as autonomous and their readiness for autonomous learning differed from each other. The teachers' opinions were based on the relationship between well-being and autonomy. Ryff explains this relation by stating that psychological wellbeing is an aspect of autonomy, goals in life, personal development, selfacceptance, and an individual's good relationship with others (1989, cited in Harrington \& Loffredo, 2007). With a sense of psychological security, learners can improve themselves more and better prepare themselves for real life (İlin \& Dişlen, 2014). Young people who have emotional wellbeing are more likely to succeed in their lives as they can set their goals, achieve them, take responsibility in making decisions, offer solutions to their problems, and have effective communications (Page \& Page, 2003). That is, they can develop the characteristics of an autonomous individual. Reflecting well-being in classrooms with positive learning environments, students can be more motivated and feel more confident, and their anxiety which otherwise hinders their learning may decrease (İlin \& Dişlen, 2014). When they have more positive self-perceptions and perceptions about learning content, students become more active in learning by trusting themselves to take responsibility for their learning and can gradually develop autonomy.

According to the teacher participants, a lack of materials in education also may hinder the readiness of students to become autonomous. As both 
the learner and the learning environment are always changing (Dent-Read \& Zukow-Goldring, 1997), the materials in the learning environment should be active and needs-based. The fact that obtaining knowledge outside the classroom has become easier and more popular by means of technological development contributes greatly to the development of autonomy (Gremmo \& Riley, 1995). Numerous materials to promote autonomy can be used for learners during the language-teaching process. That is to say, formal teaching can naturally promote learner autonomy when it is carefully designed and implemented (Ellis \& Sinclair, 1989).

Some of the teachers expressed that the learners were not much aware of their roles in their learning processes or learning strategies for demonstrating their potential autonomy. Their opinions were based on the importance of language awareness. When learners have awareness, they can decide on their goals, plans, activities, and learning strategies; then, they can control their own progress and become active in their learning processes (Holec, 1981).

The teachers also explained that not being native speakers of the language, the students had difficulties in becoming autonomous learners. Although it is possible to say that a non-native speaker can achieve nativelike competence (Calvino, 2011), language learners should be aware that language learning is a process. When learners experience the target language more extensively, they may become more capable of observing the language and developing strategies for controlling their learning.

In conclusion, the teacher participants implied that their students felt ready for autonomy; however, they needed more support in strengthening their perceptions of autonomy. If students are ready to engage in independent learning, then they should be given the opportunity and encouraged to perceive themselves as being capable of monitoring their learning.

The finding that both students' perceptions of autonomy and their readiness for autonomy were high is consistent with the findings of Altunay and Bayat (2009) and Ünal (2015). Since students have positive perceptions of autonomy, this means that they perceive themselves as capable of performing as autonomous learners. Thus, they endeavor to take responsibility for their language learning. In parallel with the study of 
Koçak (2003), students also feel ready to behave autonomously. On the other hand, the present study's finding regarding the fact that the learners' readiness for autonomy was higher than their perceptions of autonomy is not consistent with the findings of Ylldirım (2008). He supports that their perceptions of learner autonomy are related to their readiness, explaining that when learners are aware of the necessity to take responsibility for their learning, they use their abilities to do so. Thus, this conflicting result can contribute to and potentially complicate existing studies about learner autonomy.

\section{Conclusion and Suggestions for Further Research}

This study investigated the effects of grade and gender on students' perceptions of autonomy as well as the relationship between students' perceptions of autonomy and their readiness for autonomy. Moreover, teachers' and students' opinions about these relationships were taken into consideration. The findings revealed that learners' perceptions about autonomy and their readiness to take autonomous actions were related to each other. The students needed to be supported and encouraged. When the reasons behind their negative ideas about autonomy were eliminated, they would probably perceive themselves as being more autonomous. In conclusion, this study implies that teachers' awareness of learner autonomy could enable them to give their students the required skills knowledge and encourage them in an autonomous language-learning process. Their perceptions likely would increase alongside their readiness for autonomy, as there was a correlation between their perceptions and their readiness.

Most importantly, this study suggests that students' perceptions and readiness for autonomy in language learning should be examined in advance of an effective autonomous language- learning process, as their potential for autonomy can be affected both positively and negatively by their beliefs (Cotterall, 1995a.). Refugee learners, in particular, need to be understood before the commencement of their language-learning in different countries whose cultures and educational system are new to them. When learners become more aware of themselves and teachers become 
more aware of their students, they can commence a more efficient learning process and overall integration into a given educational system.

\section{Acknowledgements}

This article was generated from the MA thesis written by the first and supervised by the second author.

\section{References}

Al Riyami A., Afifi, M., \& Mabry R.M. (2004). Women's autonomy, education and employment in Oman and their influence on contraceptive use. Reprod Health Matters, 12(23), 144-54.

Altunay, U. \& Bayat, Ö. (2009). The relationship between autonomy perception and classroom behaviors of English language learners. Journal of Language, 144, 125-134.

Bacon, S. \& Finnemann, M. (1992). Sex differences in self-reported beliefs about foreign language learning and authentic oral and written input. Language Learning, 42, 471-495. doi.10.1111/j.14671770.1992.tb01041.x

Barfield, A., Ashwell, T., Carroll, M., Collins, K., Cowie, N., Critchley, M., \& Robertson, M. C. (2001). Exploring and defining teacher autonomy: A collaborative discussion. In A. S. Mackenzie and E. McCafferty (Eds.), Developing autonomy, proceedings of the college and university educators' 2001 conference, Shizuoka, japan (pp. 21722). Tokyo: The Japan Association for Language Teaching. Retrieved from http://www.encounters.jp/mike/professional/publications/tchauto.htm 1

Bartle, S. B.; Anderson, S. A. \& Sabatelli, R. M. (1988). A model of parenting style, adolescent individuation, and adolescent self-esteem: Preliminary findings. Journal of Adolescent Research, 4, 283-289.

Bastable S, B \& Dart M, A. (2007). Developmental stages of learner. In S. Bastable (Ed.), Nurse as educator (pp.147-198). Boston: Jones \& Barlett. 
Benson, P. (2001). Teaching and researching autonomy in language learning. London: Longman.

Benson, P. (2009). Making sense of autonomy in language learning. In R. Pemberton, S. Toogood, and A. Barfield (Eds.), Maintaining control: autonomy and language learning (pp. 13-26). Hong Kong: Hong Kong University Press. doi.10.5790/hongkong/9789622099234.003.0002

Bozkurt, N. \& Yalcin Arslan, F. (2017). The relationship between the Syrian refugee EFL learners' perceptions about learner autonomy and their readiness for autonomy in language learning, presented at 19th World Academy of Science, Engineering and Technology Conference, Berlin, 2017.

Calvino, M. A. M. (2011). Is it Possible to Achieve Native-Like Competence in Second Language Acquisition? Tlatemoani, 5.

Chamot, A. U., Barnhardt, S., El-Dinary, P.B. \& Robbins, J. (1999). The learning strategies handbook. White Plains, NY: Longman.

Chan, V., Spratt, M., \& Humphreys, G. (2002). Autonomous language learning: Hong Kong tertiary students' attitudes and behaviors. Evaluation \& Research in Education, 16(1), 1-18. doi.10.1080/09500790208667003

Chandler, C. L., \& Connell, J. P. (1987). Children's intrinsic, extrinsic and internalized motivation: A developmental study of children's reasons for liked and disliked behaviors. British Journal of Developmental Psychology, 5, 357-365.

Coleman, J. (1961). The adolescents society. Glencoe, IL: Free Press. Cotterall, S. (1995a). Developing a course strategy for learner autonomy. English Language Teaching Journal, 49(3), 219-227. doi.10.1093/elt/49.3.219

Cotterall, S. (1995b). Readiness for autonomy: Investigating learner beliefs. System, 23(2), 195-205. doi.10.1016/0346-251X(95)00008-8 D'ailly, H. (2003). Children's autonomy and perceived control in learning: A model ofmotivation and achievement in Taiwan. Journal of Educational Psychology, 95(1), 84-96. doi.10.1037/00220663.95.1.84 
Deci, E. (1995). Why we do what we do: The dynamics of personal autonomy. New York, NY: G.P. Putnam's Sons.

Dent-Read, C. \& Zukow-Goldring, P. (1997). Introduction: ecological realism, dynamic systems, and epigenetic systems approaches to development. In C. Dent-Read and P. Zukow-Goldring (Eds.), Evolving explanations of development: ecological approaches to organism-environment systems (pp. 1-22). Washington, DC:

American Psychological Association.

Dickinson, L. (1987). Self-instruction in language learning. Cambridge, UK: Cambridge University Press.

Dickinson, L. (1991). Self-instruction in language learning. Cambridge: Cambridge University Press.

Dickinson, L. (1995). Autonomy and motivation a literature review. System, 23(2), 165-174. doi.10.1016/0346-251X(95)00005-5

Dornbusch, M.S., Erickson, K. G., Laird, J., \& Wong C. A. (2001). The relation of family and school attachment to adolescent deviance in diverse groups and communities. Journal of Adoloscent Research, 16(4), 396-422.

Dörnyei, Z., \& Csizér, K. (1998). Ten commandments for motivating language learners: results of an empirical study. Language Teaching Research, 2(3), 203-29.

Douvan, E., \& Adelson, J. (1966). The adolescent experience. New York: Wiley.

Ehrman, M. E., \& Oxford, R. L. (1990). Adult learning styles and strategies in an intensive raining setting. The Modern Language Journal, 74, 311-326.

Ellis, G. \& B. Sinclair (1989). Learning to learn English: a course in learner training. Teacher's book. Cambridge: Cambridge University Press.

Erikson, E. (1963). Childhood and society. New York: Norton.

Fazey, D., \& Fazey, J. (2001). The potential for autonomy in learning. Studies in Higher Education, 26 (3), 345-361. doi.10.1080/03075070120076309 
Feinberg, J. (1980). The child's right to an open future. In W. Aiken and H. La Follette (Eds.). Whose child? Children's rights, parental authority and the state, Totowa, New Jersey: Rowman \& Littlefield.

Fong, R. (2004). Overview of immigrant and refugee children and families. In R. Fong (Ed.), Culturally competent practice with immigrants and refugee children and families (pp. 1-18). New York: Guilfor Press.

Fraenkel, J., Wallen, N. E., \& Hyun, H.H. (2006). How to design and evaluate research in education.(6th ed.). New York: McGraw Hill.

Gan, Z. (2004). Attitudes and strategies as predictors of self-directed language learning in an EFL context. International Journal of Applied Linguistics, 14(3), 389-411. doi.10.1111/j.1473-

4192.2004.00071.x

Green, J. M., \& Oxford, R. L. (1995). A closer look at learning strategies, L2 proficiency and gender. TESOL Quarterly, 29(2), 261-297. doi.10.2307/3587625

Greenberger, E. (1984). Defining psychosocial maturity in adolescence. In. P. Kaoly and J. Steffen (Eds.), Adolescent Behavior Disorders: Foundations and Contemporary Concern (pp. 54- 81). Lexington, MA: Heath.

Greenberger, E., \& Sorenson, A. (1974). Toward a concept of psychosocial maturity, Journal of Youth and Adolescence, 3, 329-358.

Gremmo, M. \& Riley, P. (1995). Autonomy, self-direction and self-access in language teaching and learning: the history of an idea. System, 23(2), 151-164.

Harrington, R. \& Loffredo, D. A. (2007). Private self-consciousness factors and psychological well-being, Journal of Psychiatry, Psychology and Mental Health, 1(1). Retrieved August 16, 2009 from http://www.scientificjournals.org/journals2007/articles/1086.htm

Holec, H. (1981). Autonomy in foreign language learning. Oxford: Pergamon Press.

Horwitz, E.K. (1987). Surveying student beliefs about language learning. In A. Wenden \& J. Rubin (Eds.), Learner strategies in language learning (pp. 119-129). Englewood Cliffs, NY: Prentice Hall. 
Huitt, W., \& Hummel, J. (2003). Piaget"s theory of cognitive development. Retrieved from http://chiron.valdosta.edu/whuitt/col/cogsys/piaget.html

İlin, G. \& Dişlen Dağgöl, G. (2014). Students' and teachers' stance towards learner autonomy and the psychological well-being within the ELT framework. International Journal of Languages' Education and Teaching, 2 (1), 92-108.

Karabiy1k, A. (2008). The Relationship between culture of learning and Turkish preparatory students' readiness for learner autonomy (Unpublished master's thesis). Bilkent University, Ankara, Turkey. Kelly, R. (1996). Language counseling for learner autonomy: The skilled helper in self-access language learning. In R. Pemberton, E. S. L. Li, W. W. F. Or and H. D. Pierson (Eds.), Taking control: Autonomy in language learning (pp. 93-114). Hong Kong: Hong Kong University Press.

Kenny, B. (1993). For more autonomy. System, 21(4), 431-442.

Koçak, A. (2003). A study on learners' readiness for autonomous learning of English as a foreign language (Unpublished master's dissertation). Middle East Technical University, Ankara, Turkey.

Lamb, T. (2008). Learner autonomy and teacher autonomy. In T. Lamb and H. Reinders (Eds.), Learner and teacher autonomy: Concepts, realities and responses (pp. 269-281). Amsterdam: John Benjamins.

Lee, I. (1998). Supporting greater autonomy in language learning. ELT Journal. 53(4), 282-290.

Little, D. (1994). Learner autonomy: A theoretical construct and its practical application. Die Neueren Sprachen, 93(5), 430-442. Little, D. (1996). Freedom to learn and compulsion to interact. In R., Pemberton, R., E.S.L Li, W.W.F Or and H. D. Pierson, (Eds), Taking control: autonomy in language learning. Hong Kong: Hong Kong University Press.

Little, D. (2007). Language learning autonomy: Some fundamental considerations revisited. Innovation in Language Learning and Teaching, 1(1), 14-29.

Littlewood, W. (1996). Autonomyll: An anatomy and a framework. System, 24(4), 427-435. doi.10.1016/S0346-251X(96)00039-5 
Littlewood W. (2000). Do Asian students really want to listen and obey? ELT Journal, 54(1), 31-36.

Nasöz, M. (2015). Turkish EFL learners' readiness for autonomy and attitudes toward self- access center. M.S. thesis. İhsan Doğramac1 Bilkent University.

Norton, B. (2000). Identity and language learning: gender, ethnicity and educational change. Harlow: Longman.

Nunan, D. (1989). The learner-centred curriculum. Cambridge: Cambridge University Press.

Nunan D. (1997). Designing and adapting materials to encourage learner autonomy. In P. Benson and P. Voller (Eds.), Autonomy and independence in language learning (pp. 192-203). London: Longman.

Nunnally, J. C. (1978). Psychometric theory (2nd ed.). New York: McGraw-Hill.

Orawiwatnakul, W. \& Wichadee, S. (2017). An Investigation of Undergraduate Students' Beliefs about Autonomous Language Learning. International Journal of Instruction, 10(1).

Oxford, R. (1990). Language learning strategies: What every teacher should know. Boston: Heinle \& Heinle Publisher.

Oxford, R. L. (1993). Gender differences in styles and strategies for language learning: What do they mean? Should we pay attention? In J. Alatis (Ed.), Strategic interaction and language acquisition: theory, practice, and research (pp. 541-557). Washington, DC: Georgetown University Press.

Oxford, R. L., Nyikos, M. \& Ehrman, M. E. (1988). Vive la différence? Reflections on sex differences in use of language learning strategies. Foreign Language Annals, 21 (4), 321-329. doi.10.1111/j.19449720.1988.tb01076.x

Page, R. M. \& Page, T. S. (2003). Fostering emotional well-being in the classroom. Sudbury, MA: Jones and Bartlett Publishers.

Purdie, N.; Carrol, A. \& Roche, L. (2004). Parenting and Adolescent SelfRegulation. Journal of Adolescence, 27, 663-676.

doi.10.1016/j.adolescence.2004.01.002 
Quinn, J.T. (1974). Theoretical foundations in linguistics and fields.

Responding to New Realities. . ACTFL Review of Foreign Language Education, $5,25 \mathrm{p}$.

Rind, I. A. (2015). Gender Identities and Female Students' Learning Experiences in Studying English as Second Language at a Pakistani University. Cogent Education, 2(1), 1-11. doi.10.1080/2331186X.2015.1115574

Rubin, J. (1975). What the 'good language learner' can teach us. TESOL Quarterly, 9, 41-51.

Ryff, C. D. (1995). Psychological well-being in adult life. Current Directions in Psychological Science, 4, 99-104.

Salem, Nada. M. (2006). The role of motivation, gender and language learning strategies in EFL (Unpublished master's dissertation). American University of Beirut.

Santrock, J. W. (2006). Life-span development (10th ed.). Boston: McGraw- Hill.

Sheldon, K. M. \& Kasser, T. (2001). Getting older, getting better? Personal strivings and psychological maturity across the lifespan.

Developmental Psychology, 37, 491-501.

Sheldon, M. K., Kasser, T., Houser-Marko, L., Jones, T. \& Turban, D. (2005). Doing One's Duty: Chronological Age, Felt Autonomy, and Subjective Well-Being. European Journal of Personality Eur. J. Pers., 19, 97-115.

Stevens, J. (1986) Applied Multivariate Statistics for the Social Sciences. Hillsdale, New Jersey: Lawrence Erlbaum Associates.

Sy, B. M. (1994). Sex differences and language learning strategies. Paper presented at the 11th Conference of Teachers of English to Speakers of Other Languages of the Republic of China, Taiwan.

Thanasoulas, D. (2000). What is learner autonomy and how can it be fostered? The Internet TESL Journal, Vol. VI, No. 11, November 2000. Retrieved from http://iteslj.org/

Tung, S., \& Dhillon, R. (2006). Emotional autonomy in relation to family environment: A gender perspective. Journal of the Indian Academy of Applied Psychology, 32(3), 201-212. 
Ushioda, E. (2011). Why autonomy? Insights from motivation theory and research. Innovation in Language Learning and Teaching, 5(2), 221232.

Ünal, S. (2015). (Mis)Match Between Teacher-Learner Autonomy

Perceptions and Its Relationship with EFL Learners' Achievement in Language Learning. (Published Master's Thesis). Yeditepe University, Istanbul.

Vander Zandel, J. W., Crandell, T. L. \& Crandell, C. H. (2007). Human development $\left(8^{\text {th }}\right.$ ed.). Boston: McGraw- Hill.

Victori, M., \& Lockhart, W. (1995). Enhancing metacognition in selfdirected language learning. System, 23(2), 223-234.

Watanabe, Y. (1990). External variables affecting language learning strategies of Japanese EFL learners: Effects of entrance examination, years spent at college/university, and staying overseas (Unpublished master's dissertation). Lancaster University, Lancaster, England.

Yıldırım, O. (2008). Turkish EFL learners' readiness for learner autonomy. Journal of Language and Linguistic Studies, 4, 65-80.

Zhou, Q. \& Chen, S. (2005). The mode of promoting learner autonomy for non-English majors through classroom instruction. US-China Education Review, 11(2), 46-52.

Zou, X. (2011). What happens in different contexts and how to do learner autonomy better? Teacher Development: An International Journal of Teachers' Professional Development, 15(4), 421-433. 
REMIE-Multidisciplinary Journal of Educational Research, 8(2) 145

Nilcan Bozkurt is a teacher at the Ministry of Education in Adana, Turkey.

Fadime Yalcin Arslan is an assistant professor at English Language Teaching Department, Faculty of Education, Gaziantep University in Gaziantep, Turkey.

\section{https://orcid.org/0000-0003-0644-5636}

Contact Address: Fadime Yalcin Arslan. English Language Teaching Department, Faculty of Education, Gaziantep University, 27310, Gaziantep / Turkey.

E-mail: fyalcin80@gmail.com 